\title{
PENYUSUNAN INSTRUMEN TES BERBASIS HIGH ORDER THINKING SKILL DI SMAK ST. JOANNE BAPTISTA WOLOSAMBI
}

\author{
Melkior Wewe ${ }^{1)}$, Natalia Rosalina Rawa2), Maria Editha Bela ${ }^{3)}$, Maria Carmelita Tali \\ Wangge $^{4)}$, Wilibaldus Bhoke ${ }^{5}$ \\ 1,2,3,4,5)Program Studi Pendidikan Matematika \\ 1,2,3,4,5)Sekolah Tinggi Keguruan dan IImu Pendidikan Citra Bakti \\ ${ }^{1)}$ melkiorwewe1@gmail.com, ${ }^{2)}$ nataliarosalinarawaw@gmail.com, ${ }^{3)}$ itabell09@gmail.com \\ ${ }^{4)}$ carmelitawangge@gmail.com, ${ }^{5)}$ wilibaldusbhoke87@gmail.com
}

\begin{tabular}{l} 
Histori artikel \\
\hline Received: \\
15 Maret 2020 \\
Accepted: \\
12 April 2020 \\
Published: \\
15 April 2020 \\
\end{tabular}

\begin{abstract}
Abstrak
Kegiatan Pengabdian masyarakat di SMAK st. Joanne Baptista Wolosambi dilakukan berangkat dari permasalahan kurangnya pemahaman pendidik tentang tes berbasis High Order Thinking Skill (HOTS). Kegiatan ini bertujuan untuk meningkatkan kompetensi guru pada aspek kompetensi pedagogik dan komptensi profesionalisme. Metode kegiatan adalah wawancara, diksusi dan pelatihan. Rangkaian kegiatan berhasil namun ada beberapa peserta belum memahami cara menyusun intrumen berbasis High Order Thinking Skill (HOTS). Artinya dari kompetensi pedagogik dan kompetensi profesional pada umumnya para guru sudah memahami dengan baik dan dapat mengimplementasikan dalam proses pengembangan instrumen.
\end{abstract}

Kata-kata Kunci: Instrumen tes, HOTS 
Abstract Community service activities at SMAK St. Joanne Baptista Wolosambi was conducted from a lack of understanding of educators about HOTS-based tests. This activity aims to improve the teacher's complications on the aspects of pedagogic and professional complications. Methods of activities used Wawancaraa, discussion, training. The series of activities was successful but some participants did not understand how to construct HOTS-based instruments.

Key words: Test instruments, HOTS

\section{PENDAHULUAN}

Evaluasi dilaksanakan pada setiap jenis dan jenjang pendidikan bertujuan untuk mengendalikan kualitas pendidikan secara menyeluruh dan berkelanjutan sebagai bentuk akuntabilitas penyelenggara kepada pihak yang berkepentingan, sebagaimana ditetapkan oleh Undang-undang Sistem Pendidikan Nasional Pasal 57. Evaluasi dilakukan terhadap peserta didik, lembaga, dan program pendidikan pada jalur formal dan nonformal untuk semua jenjang, satuan, danjenis pendidikan.

Menurut Popham 2009, Penilaian mempunyai manfaat yang urgen dalam menentukan suatu keberhasilan pendidikan, dimana akan memberikan dampak yang signifikan dalam setiap kegiatan pembelajaran. Selanjutnya Mardapi (2008) dengan hasil dari penilaian dijadikan sebagai untuk merumuskan suatu kebijakan baru.

Setiadi (2016), menjelaskan tujuan dari penilaian yang diharapkan dari kurikulum 2013 untuk menilai kemampuan dari setiap lulusan yang mengikuti program pembelajaran oleh guru melalui prosedur dan teknik penyusunan instrumen tes sampai pada tahap pelaporan hasil yang mencakup aspek afektif, pengetahuan dan keterampilan. Instrumen tes yang dikembangkan dijadikan sebagai alat ukur kemampuan siswa merupakan alat ukur yang mampu mengasah kemampuan peserta didik untuk lebih berpikir kritis dalam memecahkan masalah dari materi pelajaran yang didapatkan.

Penyempurnaan kurikulum 2013 antara lain pada standar isi diperkaya dengan kebutuhan peserta didik untuk berpikir kritis dan analitis sesuai dengan standar internasional, sedangkan pada standar penilaian memberi ruang pada pengembangan instrumen penilaian yang mengukur berpikir tingkat tinggi. Penilaian hasil belajar diharapkan dapat membantu peserta didik untuk meningkatkan kemampuan berpikir tingkat tinggi ( Higher Order Thinking Skills (HOTS), karena berpikir tingkat tinggi dapat mendorong peserta didik untuk berpikir secara luas dan mendalam tentang materi pelajaran.

Programme for International Student Assessment (PISA) 2018 melaporkan hasil studinya yaitu kemampuan peserta didik pada aspek memahami informasi, teori, analisis dan pemecahan masalah, penggunaan alat dan mencari tau dalam pemecahan masalah pada umumnya masih rendah. Hasil ini dapat disebakan karena literasi membaca, literasi matematika, lietarsi sains, peserta didik di Indonesia sangat rendah, Kemendikbud (2017). 
Data tersebut menunjukkan bahwa terbiasanya peserta didik dengan instrumen tes pada level C1-C3 sehingga menyebabkan peserta didik sangat sulit untuk menyelesaikan soal-soal yang membutuhkan penalaran matematis untuk memecahkan masalah, yang membutuhkan kemampuan berpikir kritis yang tinggi. Sejalan dengan hasil penelitian yang dilakukan oleh Ayuningtyas (2016) bahwa guru dalam proses pembelajaran untuk mengukur komptensi siswa cenderung menggunakan soal pada level C1-C3 dan kadang untuk berinovasi dalam mengembangkan soal pada level C4-C6. Permasalahan tersebut menunjukkan bahwa kompetensi guru pada aspek kompetensi pedagogik dan aspek profesional, indikator pengembangan evaluasi hasil belajar dan penguasaan konsep materi berbasis HOTS masih belum memuaskan dan boleh disebut masih sangat rendah.

Kenyataan di atas juga dialami oleh 25 orang guru di SMAK Santo Joanne Baptista Wolosambi. Pertemuan dengan Kepala Sekolah dan guru-guru pada tanggal 21 November 2019, diperoleh beberapa permasalahan sebagai berikut. 1) guru menyusun instrumen tes tidak membuat kisi-kisi tes, 2) Instrumen tes yang disusun oleh guru diambil dari buku referensi atau dari internet dengan tidak memperhatikan kemampuan yang akan diukur, serta instrumen yang disusun pada level level C1-C3.Permasalahan tersebut disebabkan karena rendanya profesionalisme guru terhadap profesinya, baik aspek pedagogik maupun aspek profesionalisme.

Tujuan dari kegiatan workshop ini adalah untuk memberikan pendampingan pengembangan instrumen test berbasis HOTS pada guru-guru SMAK St. Joanne Baptista sehingga dapat diimplentasikan dalam proses pembelajaran maupun pada penilaian komptensi peserta didik.

\section{METODE PELAKSANAAN}

Pelaksnaan kegiatan ini menggunakan metode : 1) Observasi dan wawancara 2) Menyiapkan Materi, 3) Menyiapkan data pendukung, 3) Menyampaikan materi, 4) Pendampingan Kegiatan, Presentasi.

1. Persiapan

Pada tahap persiapan dilakukan wawancara dengan guru dan siswa serta observasi terhadap proses pembelajaran di SMAK St. Joannes Baptista. Wawancara dilakukan untuk memperoleh gambaran tentang kesulitan guru dalam menyusun soal test berbasis HOTS, sedangkan observasi dilakukan untuk mengetahui masalah apa yang terdapat dalam proses belajar mengajar. Wawancara dengan siswa untuk memperoleh gambaran awal tentang pelaksanaan tes yang dilakukan oleh guru disekolah. Setelah diketahui masalahnya maka disusun suatu solusi untuk diterapkan dalam tahap pelaksanaan. Menyiapkan materi dan data-data pendukung yang berkaitan dengan HOTS.

2. Pelaksanaan Proses 
Pelaksanaan terbagi menjadi 2 yaitu pemaparan Materi dan pelatihan. Pemaparan materi dilakukan untuk memberi gambaran umum tentang instrumen HOTS sehingga Bapak dan Ibu Guru memahami tentang Instrumen HOTS. Pelatihan pengembangan instrumen berbasis HOTS. Pelatihan ini dibagi dalam bentuk 5 kelompok yaitu kelompok Bahasa, Kelompok Sosial, Kelompok matematika, kelompok Agama dan kelompok mulok. Selama kegiatan peserta didamping oleh narasumber/pemateri. Setelah kegiatan penyusunan instrumen tes dilanjutkan dengan presentasi dari setiap kelompok dan kelompok lain memberikan tanggapan.

Metode yang digunakan dalam kegiatan ini adalah metode ceramah, diskusi, demonstransi dan unjuk kerja.tahapan kegiatan dijelaskan pada Tabel 1 berikut ini.

Tabel 1. Permasalahan dan Metode Pelaksanaan Kegiatan

\begin{tabular}{ll}
\hline \multicolumn{1}{c}{ Permasalahan } & \multicolumn{1}{c}{ Metode Pelaksanaan Kegiatan } \\
\hline $\begin{array}{l}\text { Pengetahuan dan pemahaman guru di } \\
\text { SMAK Santo Joanne Baptista tentang } \\
\text { instrumen tes berbasis HOTS masih } \\
\text { rendah }\end{array}$ & $\begin{array}{l}\text { Dengan menggunakan metode } \\
\text { ceramahuntuk memparkan tentang } \\
\text { hakikat dari HOTS itu sendiri. }\end{array}$ \\
\hline $\begin{array}{l}\text { Keterampilan guru-guru di SMAK } \\
\text { Santo Joanne Baptista dalam } \\
\text { menyusun soal-soal Higher Order }\end{array}$ & $\begin{array}{l}\text { Memberikan pelatihan dan } \\
\text { pendampingan dalam mengembangkan } \\
\text { Thinking Skill (HOTS) yang dapat } \\
\text { mengembangkan daya berpikir kritis } \\
\text { siswa masih rendah }\end{array}$ \\
$\begin{array}{l}\text { dari persiapan awal sampai pelaporan } \\
\text { penilaian. }\end{array}$
\end{tabular}

\section{HASIL DAN PEMBAHASAN}

Hasil

Dalam mengimplementasikan proses pembelajaran yang dituntut dalam kurikulum 2013 yang dijadikan sebagai Kompoenen yang sangat esensial Pembelajaran dan penilaian hasil belajar berhasil atau tidak suatu pembelajaran diketahui melalui proses penilaian. Karena dengan penilaian dijadikan sebagai alat untuk mengevaluasi pembelajaran. Kesulitan utama yang dihadapi pendidik di SMAK St Joanne Baptista rendahnya pemahaman dalam mengembangkan instrumen test berbasis HOTS, dari berbagai aspek seperti fakta, konsep, dan prosedur serta keterampilan berpikir tingkat tinggi untuk pemecahan masalah.

Berkaitan dengan permasalahan yang dialami pendidikan di SMAK Santo Joanne Baptista, tim dosen dari program studi pendidikan Matematika STKIP Citra Bakti, melakukan kegiatan tridarma pada darma pengabdian dengan judul penyusunan instrumen tes Berbasis High Order Thinking Skill (HOTS) di SMAK st. Joanne Baptista Wolosambi

Kegiatan ini dilaksanakan dengan tujuan untuk memberikan pendampingan untuk pengembangan test berbasis High Order Thinking Skills (HOTS) pada guru-guru SMAK St. Joanne Baptista Wolosambi, sehingga guru dapat memahami tentang instrumen tes berbasis High Order Thinking Skills (HOTS), dan dapat diimpelentasikan dalam proses 
pembelajaran maupun pada saat penilaian untuk mengukur komptensi siswa dalam pencapaian indikator yang diharapkan.

Instrumen test berbasis HOTS adalah instrumen untuk mengukur kemampuan tingkat tinggi dalam pemecahan masalah. Karekateristik Instrumen tes berbasis HOTS adalah mengaitkan konsep dan informasi yang berbeda, menerapkan proses berdasarkan informasi dalam memecahkan masalah, menalar secara kritis berdasarkan informasi. Meskipun demikian,. Instrumen test berbasis HOTS bukan merupakan kumpulan soal yang sukar, namun instrumen test berbasis HOTS merupakan suatu instrumen untuk mengukur aspek metakognitif peserta didik, bukan sekedar mengukur aspek faktual, konseptual, dan prosedural, tetapi bagiamana peserta didik mendeskripsikan kemampuan dengan mangaitkan beberapa konsep dan strategi dalam menafsirkan, memecahkan suatu masalah, menemukan konsep baru, dan bernalar yang baik sehingga dapat mengambil suatu keputusan akhir yang tepat. Tingkatan pengetahuan taksonomi Bloom revisi oleh Anderson \& Krathwohl (2001), terdiri dari kemampuan mengetahui, kemampuan memahami, kemampuan menerapkan, kemampuan menganalisis, kemampuan mengevaluasi dan kemampuan mengkreasi. Intrumen test dikatakan HOTS jika intstrumen tersebut mampu mengukur kemampuan pada tingkatan melakukan analisis, melakukan evaluasi dan melakukakn kreasi atau mencipta

Pengetahuan mengenai instrumen tes berbasis HOTS perlu diketahui oleh setiap pendidik dalam melaksanakan pembelajaran dengan menggunkan pendekatan scientific pada kurikulum 2013, karena dalam kurikulum 2013 yaitu mengenai standar penilaian yang memberikan otonomi kepada pihak sekolah atau pendidik untuk mengembangkan instrumen penilaian untuk mengukur berpikir tingkat tinggi, sesuai dengan karakteristik dari setiap sekolah dan siswa tersebut. Sehingga pendidik diharapkan mampu mengembangkan instrumen berbasis HOTS, yang akan berdampak pada peserta didik terbiasa dengan test berbasis HOTS, siswa memiliki kemampuan untuk menyelesaikan soal dengan tingkat kesulitan yang berbeda-beda.

Kegiatan pengabdian dilaksanakan di SMAK Santo Joanne Baptista pada tanggal 7 Desember 2019, dengan peserta 25 peserta dibagi dalam kelompok dari rumpun ilmu yang berbeda. Kegiatan pengabdian dilaksanakan dari pukul 07.30 - 17.00 WIT. Luaran yang diharapkan dari kegiatan pengabdian ini berupa produk kisi-kisi dan instrumen tes.

Kegiatan dibagi menjadi 2 tahap yaitu 1) Pemaparan Materi dan pelatihan. Pemaparan materi dilakukan untuk memberi gambaran umum tentang HOTS sehingga Bapak dan Ibu Guru memahami wawasan tentang HOTS. Pada awal kegiatan dilakukan curah pendapat selama 15 menit, untuk memperoleh gambaran awal tentang pemahaman awal guru. sekaligus melakukan penjajakan awal tentang pemahaman awal peserta terkait konsep penyusunan instrumen test berbasis HOTS. Dari hasil curah pendapat diperoleh 
pemahaman guru tentang soal HOTS masih rendah, hal ini disebabkan kurangnya informasi baik dari sekolah maupun dinas terkait untuk sosialisasi tentang HOTS, mapun pelatihanpelatihan yang berkaitan dengan penyusunan instrumen tes berbasis HOTS. Dari hasil curah pendapat juga ditemukan ada 15 orang guru yang menyusun soal tidak menggunakan kisikisi soal. Dalam kegiatan pemaparan materi, pemateri memaparkan tentang pengertian HOTS karakteristik HOTS, langkah-langkah mengembangkan instrumes tes berbasis HOTS. Temuan-temuan selama pemaparan materi salah satu peserta pelatihan menanyakan tentang taksonomi, perbedaan kata kerja operasional taksonomi Bloom aspek pengetahuan dan psikomotor, apa yang dimaksudkan dengan stimulus dalam kaitan dengan instrumen berbasis soal HOTS? Berdasarkan pertanyaan yang disampaikan, pemateri menjelaskan jika konsep taksonomi merupakan kriteria yang digunakan oleh pendidik dalam mengevaluasi kualitas pembelajaran yang dilakukan oleh seorang pendidik. Taksonomi merupakan kata kerja operasional yang menggambarkan kompetensi yang mau diperoleh melalui suatu pembelajaran. Kata kerja operasional dijadikan acuan untuk merumuskan indikator oleh pendidik saat mengembangkan perangkat pembelajaran. Pendidik seringkali mengalami kesulitan dalam menempatkan konten pembelajaran karena taksonomi Bloom bersifat liniear. Revisi taksonomi Boloom oleh Anderson dan Krathwohl mengubah dari kata benda menjadi kata kerja. Setiap aspek afektif, kogniti dan psikomotorik mempunyai rumusan indikator berbeda-beda. Pemateri menjelaskan taksnomi yang digunakan pada saat ini merupakan taksnomi Bloom hasil revisi oleh Anderson, dan Krathwohl. Perbedaan Taksonomi Bloom dan Anderson \& Krathwohl pada aspek kognitif disajikan pada Tabel 2 berikut ini

Tabel 2. Perbedaaan Taksonomi Bloom dan Anderson

\begin{tabular}{cc}
\hline Taksonomi Bloom & Taksonomi Anderson\&Krathwolh \\
\hline Pengetahuan & Mengingat \\
\hline Pemahaman & Memahami \\
\hline Penerapan & Menerapkan \\
\hline Analisis & Menganalisis \\
\hline Sintesis & Menilai \\
\hline Penilaian & Menciptakan \\
\hline
\end{tabular}

Pemateri juga menjelaskan jika stimulus merupakan rangsangan.Dalam konteks penyusunan instrumen tes berbasis HOTS, stimulus merupakan dasar dalam merumuskan suatu pertanyaa. Dalam konteks pengembanganinstrumen test berbasis HOTS, stimulus harus kontekstual dan menarik, yang dikembangkan dari isu-isu global, budaya, adat, atau kasus-kasus di daerah atau berbagai keunggulan yang terdapat di daerah tertentu. Pendidik dituntut kreatif, inovatif karena akan berpengaruh pada kualitas instrumen tes yang dihasilkan.

Temuan saat praktik penyusunan soal, ada beberapa guru belum menyelesaikan menyusun soal yang diberikan, karena waktu tidak memungkinkan. Hal ini disebabkan 
peserta menyusun instrumen dari awal, sedangkan yang lain hanya merevisi soal yang sudah ada, karena sebelumnya peserta sudah menyiapkan kisi-kisi dan instrumen tes. Bagi peserta yang sudah memiliki kisi-kisi dan instrumen soal pemateri melakukan bimbingan dengan mengkoreksi dan mengembalikan kepada peserta untuk diperbaiki, sedangkan bagi peserta yang belum menyelesaikan soal diberikan kesempatan untuk menyusun soal di rumah dan berdiskusi menggunakan aplikasi Whatsapp. Pelatihan pengembangan instrumen berbasis HOTS, dibagi dalam bentuk 5 kelompok yaitu kelompok Bahasa, Kelompok Sosial, Kelompok matematika, kelompok Agama dan kelompok mulok. Setelah kegiatan penyusunan instrumen tes dilanjutkan dengan presentasi dari setiap kelompok dan kelompok lain memberikan tanggapan.

Terlaksannya kegiatan pendampingan penyusunan instrumen berbasis HOTS didukung oleh beberapa faktor seperti tingginya minat dan antusias dari setiap peserta, serta rasa ingin tau yang tinggi dari setiap peserta. Sedangkan penghambatnya adalah sebagai berikut. 1) kemampuan guru dalam mengenal tingkatan taksonomi Bloom masih rendah, 2) waktu pelatihan yang terbatas, dan 3) ada beberapa peserta yang tidak membawa dokumen soal yang sudah pernah dibuat.

Harapan dari peserta untuk kegiatan berikutnya antara lain adalah: 1) jumlah peserta, dapat ditingkatkan, dengan melibatkan pendidik dari sekolah lain, 2) kegiatan seperti pelatihan pengembangan isntrumen terprogram dan terjadwal, 3) adanya kegiatan lainnya seperti pendampingan pembelajaran inovatif, pembelajaran berbasis internet, penulisan karya IImiah.

\section{KESIMPULAN}

Kegiatan pengabdian masyarakat dengan tema "Penyusunan Instrumen Tes Berbasis High Order Thinking Skill di SMAK St. Joanne Baptista Wolosambi berhasil, meskipun belum semua peserta pendampingan menguasai cara mengembangkan instrumen berbasis HOTS. Rangkaian kegiatan berhasil namun ada beberapa peserta belum memahami cara menyusun intrumen berbasis High Order Thinking Skill (HOTS). Artinya dari kompetensi pedagogik dan kompetensi profesional pada umumnya para guru sudah memahami dengan baik dan dapat mengimplementasikan dalam proses pengembangan instrumen. Kegiatan ini mendapat sambutan baik dari semua peserta karena dari 25 peserta dapat mengikuti dengan penuh antusias dari awal sampai akhir kegiatan. Keberhasilan kegiatan diukur dari keterlibatan peserta mulai dari tanya jawab, pelatihan dan pengumpulan produk yang dihasilkan berupa kisi-kis dan instrumen tes yang dikembangkan. 


\section{DAFTAR PUSTAKA}

Anderson, L. W., \& Krathwohl, D. R. (2001). A taxonomy for learning, teaching, andassesing. A revision of bloom's taxonomy of educatioanl objectives. New York: Addison Wesley Longman, Inc.

Ayuningtyas, N, (2013). Proses penyelesaian soal higher order thinking materi aljabar siswa SMP ditinjau berdasarkan kemampuan matematika siswa. Jurnal MATHEdunesa, 2(2), 80-89

Bloom, B. S. (1956). Taxonomy of educational objective cognitive domain. New York: Longmans, Green and Co.

Kemendikbud. (2017). Modul penyusunan soal HOTS. Jakarta: Direktorat Pembinaan SMA Ditjen Pendidikan Dasar dan Menengah.

Mardapi, D. (2008). Teknik penyusunan instrumen tes dan nontes. Yogyakarta: Mitra Cendikia Press.

Neni, W. \& Nurul, R. (2018). Workshop pengembangan soal higher order thinking skill (hots) bagi guru-guru MGMP IPS Kabupaten Malang. Jurnal Praksis dan Dedikasi Sosial, 1(2),73-79.

Permendikbud Nomor 23 Tahun 2016 tentang Standar Penilaian Pendidik.

Permendikbud Nomor 24 Tahun 2016 tentang Kompetensi Inti dan Kompetensi Dasar Pelajaran pada Kurikulum 2013.

Permendikbud Nomor 53 Tahun 2015 tentang Penilaian Hasil Belajar oleh Pendidik dan Satuan Pendidikan.

Popham, W. J. (2009). Instruction that up measures up. Virginia: ASCD 